\title{
A STUDY ON GEOGRAPHICAL CHARACTERISTICS OF THE KRISHNA WESTERN DELTA USING GIS AND REMOTE SENSING TECHNIQUES
}

\author{
V. Mallikarjuna ${ }^{1}$, M. Sai Lakshmi ${ }^{2}$ \\ ${ }^{I}$ Associate Professor, Department of Civil Engineering, V.R. Siddhartha Engineering College, Vijayawada-520 007, \\ Krishna District, Andhra Pradesh, India \\ ${ }^{2}$ Assistant Executive Engineer, I \& CAD Department, Irrigation Circle, Guntur - 522 004, Guntur District, Andhra
}

Pradesh, India.

\begin{abstract}
Water is a prime natural resource, basic human need and a precious national asset. Though water is considered as a renewable resource it is not unlimited, and as such, can no longer be taken for granted and has to be treated as a valuable resource. Since water is a critical resource for development of other resources, the assessment of water resources available and demand of water for various purposes is of utmost importance without which it is difficult to prepare any developmental plan. Rainfall is the main source of water which is unevenly distributed spatially and temporally. The ever increasing demand of water due to high industrialization, enormous population growth, agricultural expansion and urbanization has already created serious problems. As water demand increases, issues on water availability and demand become critical. This makes the management of water resources, such as assessing, managing and planning of water resources for sustainable use, a complex task.

Remote Sensing with its advantages of spatial, spectral and temporal availability of data covering large and inaccessible areas with in short time has become a very handy tool in assessing, monitoring and conserving land use/ land cover classification around the world. Remote Sensing integrated with Geographical Information System has been efficiently used in generating input parameters of hydrological models. The GIS and RS technology have opened new paths in water resources studies. In the present investigation, an attempt has been made to delineate the Krishna Western Delta In Andhra Pradesh, India for the assessment of spatial distribution of runoff. The GIS layers namely, Topomap, contours and Digital Elevation Model (DEM) were prepared including watershed boundary. The Digital Elevation Model (DEM) of the study area was generated in ArcGIS using Contours and Stream layers. The Georeferenced soil map has been clipped to the boundary of the Krishna Western Delta and the areas corresponding to each variety of soil is calculated in ArcGIS.
\end{abstract}

Keywords: Clipping, DEM, Digitization, GIS, RS, SOI \& Watershed.

\section{INTRODUCTION}

A watershed describes the portion of land which contains a common set of rivers and streams which all drain into a single large body of water, such as a lake, a larger river or an ocean. In India, the necessity for exact information on silt yield and basin runoff has been felt for the past two decades together with the acceleration of the watershed management for conservation and enlargement of soil and water resources.

Watershed management is the study of the relevant characteristics of a watershed focused at the sustainable distribution of its resources and the procedure of generating and implementing plans, programs, and projects to sustain and enhance watershed functions that influence the plant, animal, and human communities within a watershed boundary. Watershed management depends on managing different hydrological processes, which occur over it, principally runoff. Enormous Population growth, high industrialization, enhanced urbanization, changes in climate, land use and land cover have deteriorated the conditions of the Krishna Western Delta of Andhra Pradesh for the last few decades. A severe problem identified is that adequate water is not available during the dry season.

The water sector is very sensitive and is strongly influenced by the changes in climate and land use. Hence, it has the potential to impose additional pressures on water availability, water accessibility and water demand in the Krishna Western Delta of Andhra Pradesh. The Krishna Western Delta is situated between longitude $80^{\circ} 10^{\prime} \mathrm{E}$ and $80^{\circ} 39^{\prime} \mathrm{E}$ and latitude $15^{\circ} 50^{\prime} \mathrm{N}$ and $16^{\circ} 30^{\prime} \mathrm{N}$. The present study is an attempt to delineate the Krishna Western Delta, to compute geometric data such as area and elevation, to generate DEM with the utilization of ArcGIS and using Survey of India (SOI) Toposheets. Further, soil map for the Krishna Western Delta has been prepared. 


\section{STUDY AREA}

The Krishna Western Delta is enclosed between longitude $80^{\circ} 10^{\prime} \mathrm{E}$ and $80^{\circ} 39^{\prime} \mathrm{E}$ and latitude $15^{\circ} 50^{\prime} \mathrm{N}$ and $16^{\circ} 30^{\prime}$
N. The Krishna Western Delta covers a part of Guntur District and a part of Prakasam District in Andhra Pradesh State (Refer Fig. No. 1).

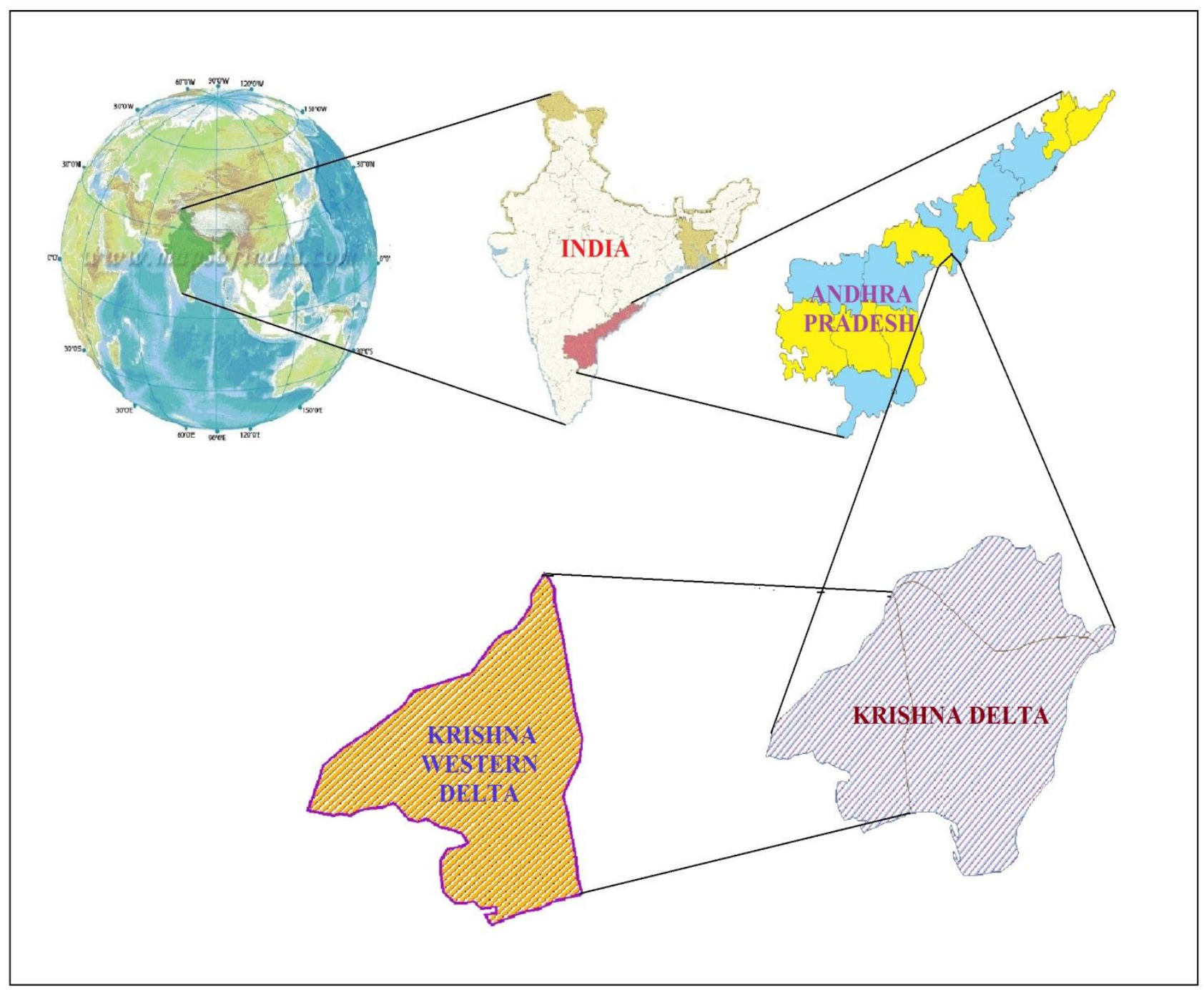

Fig 1: Location Map of the Krishna Western Delta, Andhra Pradesh

\subsection{Characteristics of the Krishna Western Delta}

The total Geographical area of the Krishna Delta is about $6931 \mathrm{Sq}$. Km. of which Krishna Western Delta covers an extent of $1895 \mathrm{Sq}$. Km. with a perimeter of about 226.48 $\mathrm{Km}$. (Table No. 1). The maximum elevation is about $15 \mathrm{~m}$ and minimum is about $3.50 \mathrm{~m}$ level. The general climatic conditions of the Krishna Western Delta are with hot summer and cold winter. The soils in the Krishna Western Delta are mainly Clayey soils and Loamy Sandy soils together constituting about $85 \%$. Silty Clayey soils, Loamy soils and sandy clayey/gravelly clayey soils are also observed in small proportions. Most of the people in the Krishna Western Delta are dependent on Agriculture which depends on the vagaries of monsoon.
Table 1 Attributes of KW Delta_Project

\begin{tabular}{|l|l|l|l|l|}
\hline FID & SHAPE & Id & $\begin{array}{l}\text { AREA } \\
(\text { Sq. Km. })\end{array}$ & $\begin{array}{l}\text { PERIMETER } \\
(\mathrm{Km} .)\end{array}$ \\
\hline 0 & Polygon & 0 & 1894.900 & 226.480 \\
\hline
\end{tabular}

\section{METHODOLOGY}

The topographic sheets which were collected from the Survey of India pertaining to the boundary of the Krishna Western Delta (Fig.No.2) were georeferenced to the Geographic coordinate system and then the georeferenced topographic sheets were Mosaicked to make up for single image of Topomap. The single Mosaicked Topomap for the Krishna Western Delta was as shown in Fig. No. 3.

The Mosaicked Topomap for the Krishna Western Delta was Georeferenced and was utilized in the development of 
Contour shape file. The Digitization process was carried out on the Mosaicked Topographic sheet and with the help of polyline feature type in Arc Catalog, the contours were digitized one by one. The contour map which was obtained from the above process was used in the generation of DEM for the Krishna Western Delta. The Digital Elevation Model, which is generally used for the representation of height information was developed for the Krishna Western Delta in Arc GIS with the help of Spatial Analyst Tools and with the addition of the layers namely boundary and contours related to the study area. The DEM, so generated for the Krishna Western Delta appears as shown in Fig. No. 4.

The satellite imagery (IRS - P6 - LISS - III image), corresponding to the Krishna Western delta was shown in the Fig. No. 5 and this imagery was utilized in the preparation of land use/ land cover map for the study area.
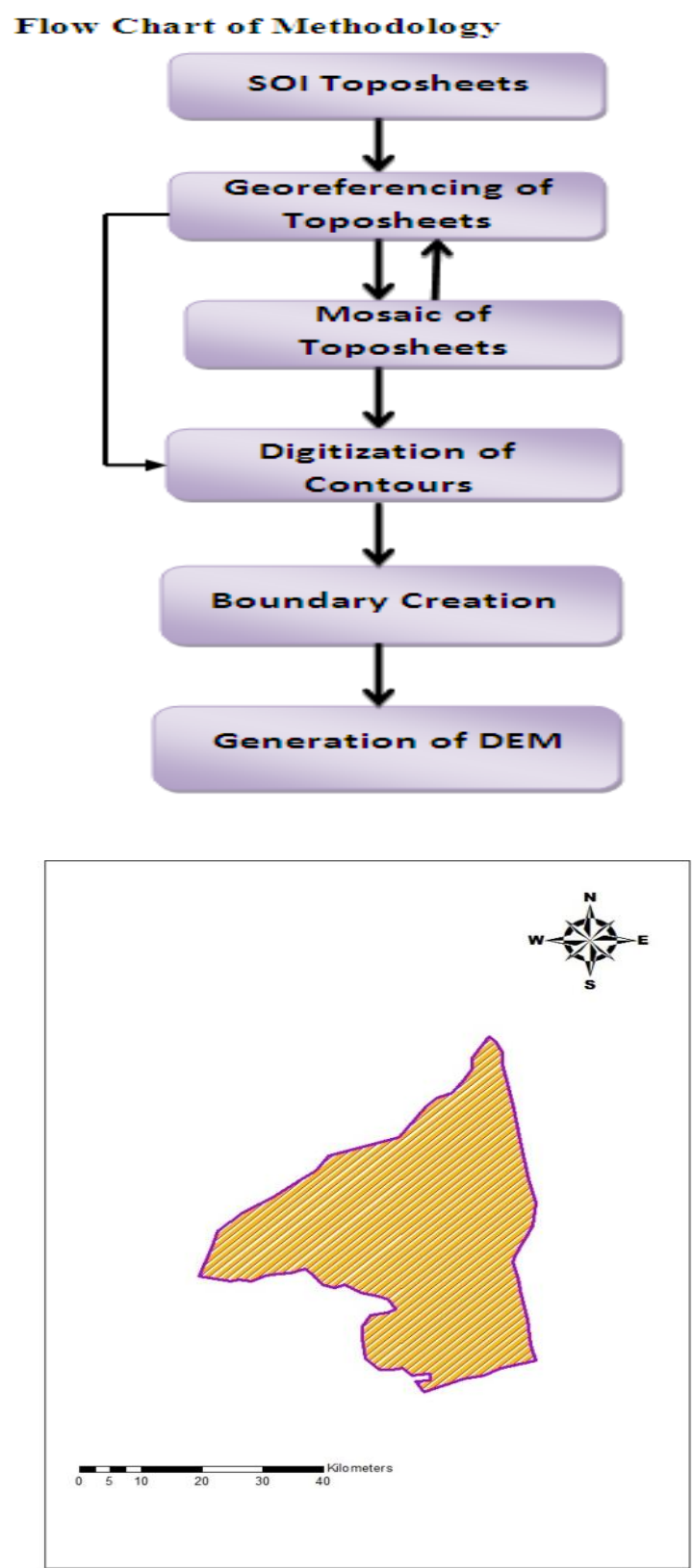

Fig 2: Boundary of the Krishna Western Delta

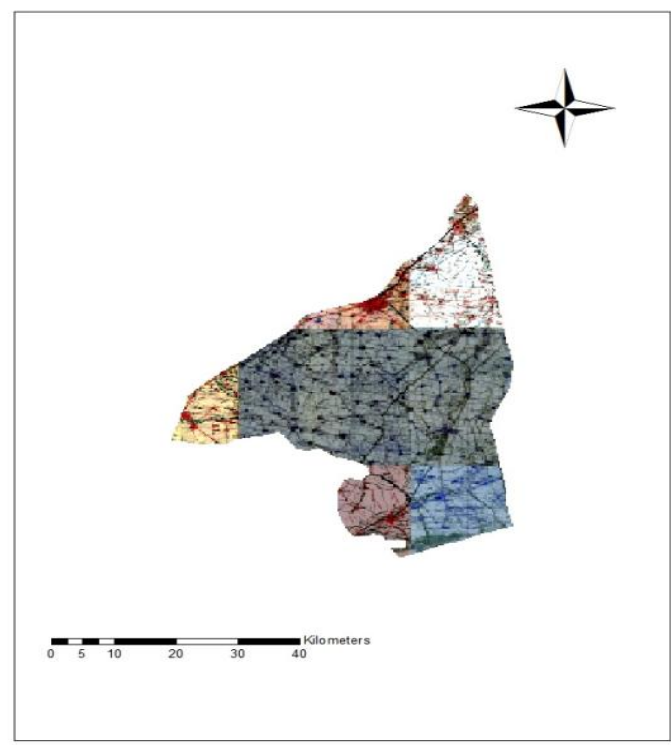

Fig 3: Mosaicked Topomap of the Krishna Western Delta

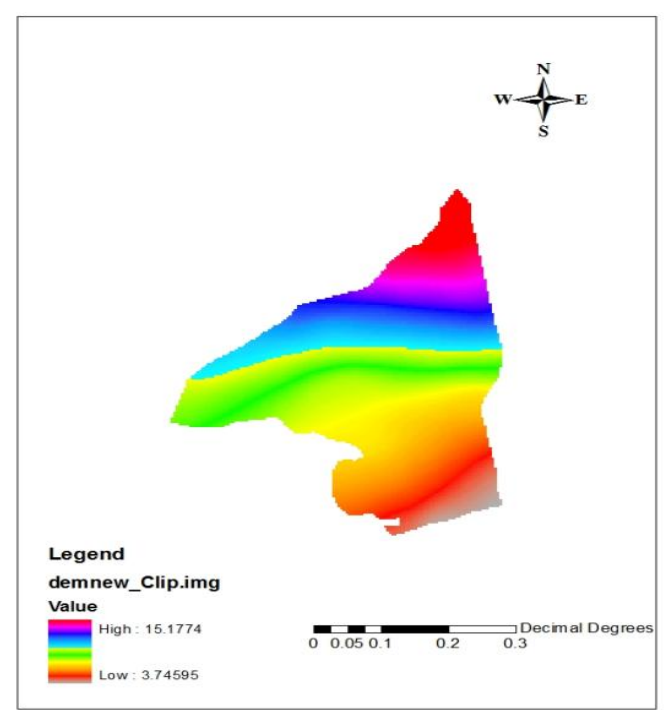

Fig 4: DEM-Stretched View-Krishna Western Delta

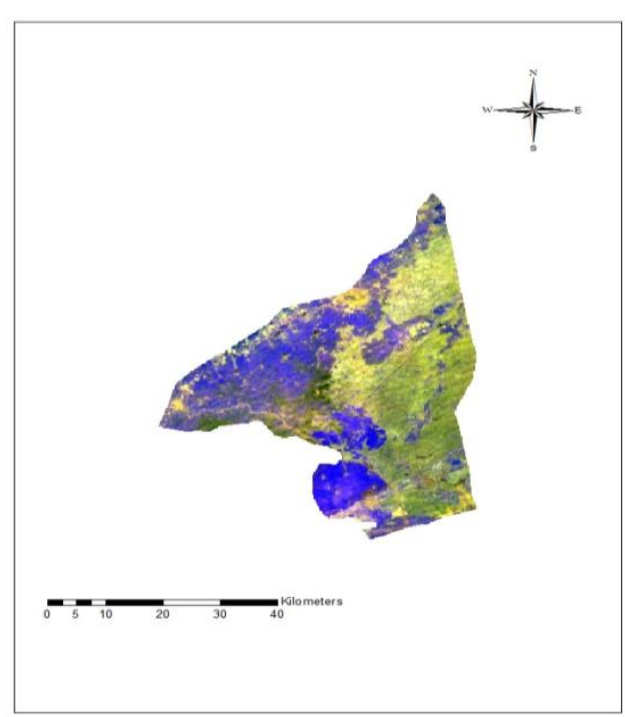

Fig 5: Satellite Imagery of the Krishna Western Delta 
The soil map corresponding to the overall Krishna Delta was taken and this map was clipped to the extent of boundary of the Krishna Western Delta. The clipped soil map corresponding to the Krishna Western Delta was as shown in Fig. No. 6. Five types of soils were observed in the Krishna Western Delta area, namely, Clayey soils, Silty clayey soils Loamy soils, Loamy sandy soils and Sandy clayey/Gravelly clayey soils. Each variety of these soils was digitized with the help of editor tool bar in Arc GIS and the corresponding areas were obtained. The areas corresponding to each variety of soils is shown in Table No. 2.

Table 2: Classification of Soils in the Krishna Western Delta

\begin{tabular}{|l|l|l|l|}
\hline S. No. & Type of Soil & $\begin{array}{l}\text { Area } \\
(\text { Sq. Km.) }\end{array}$ & $\begin{array}{l}\text { \% of Total } \\
\text { Area }\end{array}$ \\
\hline 1 & Clayey soils & 946.22 & 49.94 \\
\hline 2 & Silty Clayey soils & 74.46 & 3.93 \\
\hline 3 & Loamy soils & 128.40 & 6.78 \\
\hline 4 & Loamy Sandy soils & 685.96 & 36.20 \\
\hline 5 & $\begin{array}{l}\text { Sandy } \\
\text { Clayey/Gravelly } \\
\text { Clayey soils }\end{array}$ & 59.85 & 3.16 \\
\hline
\end{tabular}

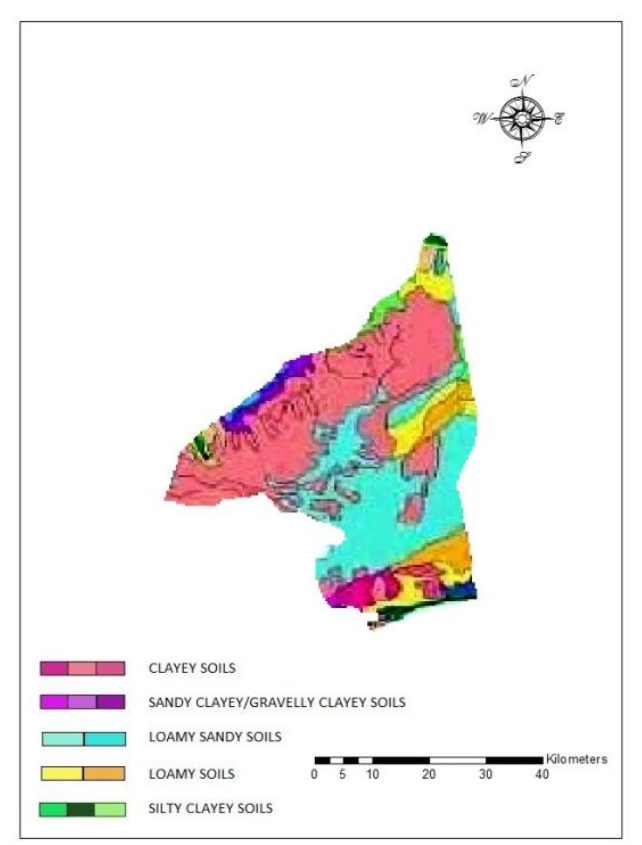

Fig 6: Soil Map of the Krishna Western Delta

\section{CONCLUSIONS}

In the present study, various Thematic maps namely boundary map, contour map, Digital Elevation model and Soil map pertaining to the Krishna Western Delta have been generated using GIS \& RS Techniques. In the same manner the geographical characteristics of any area can be studied using GIS \& RS Techniques for the development of effective management scenarios.

With the help of the satellite imagery, the Landuse / Landcover map for the Krishna Western Delta can be developed in ERDAS software and the areas under each
LULC class can be found out. By intersecting LULC map and soil map, in Arc GIS, finally we can arrive at the weighted curve number for the Krishna Western Delta which can be further utilized in the estimation of Run-off.

\section{REFERENCES}

[1]. Anuradha, C.T. and Prabhavathy, S - "Water Resources Management for Virudhunagar District using Remote Sensing and GIS", International Journal of Earth Sciences and Engineering, 3(1) - Special issue, January, 2010, pp. 55-61.

[2]. Arnold, J.G.,, Srinivasan, R., Muttiah, R.S. and Williams, J.R. - "Large Area Hydrologic Modelling and Assessment. Part I: Model Development," Journal of the American Water Resources Association, Vol. 34, No. 1, 1998, pp. 7389.

[3]. Biswas, S., Sudhakar, S. and Desai, V.R. - "Remote Sensing and Geographic Information System Based Approach for Watershed Conservation", Journal of Surveying Engineering, 2002, 128(3), pp. 108-124.

[4]. Garbrecht J., Ogden F.L., Debarry P.A. Debarry and Maidment D.R. - "GIS and Distributed Watershed Models Data Coverages and Sources", Journal of Hydrologic Engineering, 6(6), 2001, pp. 506-514.

[5]. Gosain A.K. and Sandhya Rao - "GIS based technologies for watershed management", Current Science, Vol.87, No.7, 10 October, 2004.

[6]. Jenifa latha, C., Saravanan, S. and Palanichamy, K. -“A Semi-Distributed Water Balance Model for Amaravathi River basin using Remote Sensing and GIS" - International Journal of Geomatics and Geosciences, 2010, Volume 1, No 2, ISSN 0976- 4380.

[7]. Mallikarjuna, V., Prasad, K.R.K., Udaya Bhaskar, P. and Sai Lakshmi, M. - "RS \& GIS Based Assessment of Landuse/Landcover Characteristics for Krishna Delta, Andhra Pradesh", International Journal of Engineering Research and Applications (IJERA), ISSN: 2248-9622, Vol. 2, Iss.6, November-December, 2012, pp. 746-752.

[8]. Mallikarjuna, V., Prasad, K.R.K., Udaya Bhaskar, P. and Sai Lakshmi, M. - "Watershed Modeling of Krishna Delta, Andhra Pradesh, using GIS and Remote Sensing Techniques", International Journal of Engineering Science and Technology (IJEST), ISSN: 0975-5462, Vol. 4 No. 11, November, 2012, pp. 4539 - 4545.

[9]. Prakasa Rao B.S., Pernaidu P., Sathi Devi K. and Jagadeeswara Rao, P. - "Runoff and flood estimation in Krishna River Delta Using Remote Sensing \& GIS", Journal of Ind. Geophys. Union, Vol. 15, No.2, April, 2011, pp.101-112.

[10]. Robert A. Laura, P.E., CFM; Craig Mesimer and Tim Brink, "GIS-Based Watershed Modeling", Watershed Management Conference 2005, Williamsburg, Virginia, United States, ISBN (print): 978-0-7844-0763-9, American Society of Civil Engineers, July 19-22, 2005.

[11]. Saxena, R.K., Verma, K.S., Chary, G.R., Shristava, R. and Barthwal, A.K. - "IRS-1C data application in watershed characterization and management", International $\mathrm{Jl}$. of Remote Sensing, 2000, 21(17), pp 3197-3208.

[12]. Tripathi, M.P., Panda, R.K, Pradhan, S. and Sudhakar, S. - "Run-off modeling of a small watershed using Satellite 
data and GIS", Journal of Indian Society of Remote Sensing, 2002, 30 ( 1 \& 2).

\section{BIOGRAPHIES}

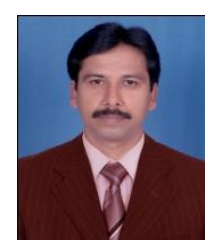

Dr. V. Mallikarjuna is presently working as Associate Professor, Department of Civil Engineering, V.R. Siddhartha Engineering College, Vijayawada - 520 007, Andhra Pradesh, India. He obtained M.E., degree in Hydraulics from Andhra University in 1995 and awarded Ph.D. degree in the stream of Water Resources Engineering in 2013. He published 06 research papers in international journals and 12 in national journals and seminar proceedings. He served as Honorary Secretary, The Institution of Engineers (India), Vijayawada Local Centre, Andhra Pradesh. His research interests are application of GIS \& Remote Sensing in the fields of Hydrological modeling, Watershed management and Water Budgeting.

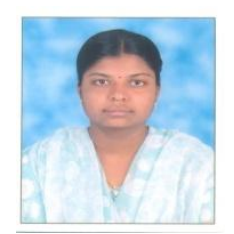

Ms. M. Sai Lakshmi is presently working as Assistant Executive Engineer, I \& CAD Department, Irrigation Circle, Guntur 522 004, Andhra Pradesh, India. She obtained her B.Tech., degree in 2010 and M.Tech., degree in 2013. She secured 2 gold medals during her graduation for academic excellence. She published 04 research papers in international journals. Earlier, she worked as Lecturer in the Department of Civil Engineering, V.R. Siddhartha Engineering College, Vijayawada for 1 year. 